less of religious identity, while the smaller institutions are privately funded and perhaps more selective with faculty hiring or even admissions. Overall, although Christian universities no longer lead higher education, where nationstates allow it, they still grow. In some senses, they grow on the margins, but then these margins are not so small or insignificant.

\section{Christian Universities Grow in Africa}

\section{Joel Carpenter}

Joel Carpenter is professor of history and director of the Nagel Institute for the Study of World Christianity at Calvin College, US. E-mail: jcarpent@calvin.edu.

C hristian higher education is growing briskly in sub-Saharan Africa. It exists at the intersection of two of the most dynamic social trends on the continent: the rapid rise of Christian adherence and the volatile growth of higher education.

A century ago, only nine million Christians resided in all of Africa, and most were in Egypt's and Ethiopia's ancient churches. By I950, this number had tripled, to about 30 million. By I970, there were II4 million Christians in Africa. Today there are an estimated 555 million African Christians-Orthodox, Catholic, Protestant, Pentecostal, and African-instituted.

African higher education's growth has also been rapid. In the early I960s, there were only 4I higher education institutions and 16,500 students in all of Africa. As of 2010, sub-Saharan Africa enrolled 5.2 million students in 668 higher education institutions, and these enrollments were more than double those in 2000.

African universities today are emerging from a turbulent half-century. The immediate postcolonial era brought high hopes with supportive governments and massive international investments. But by the I980s, African universities were suffering deep financial cuts as falling commodity prices and inflated energy prices crippled national budgets. World Bank and International Monetary Fund advisors pushed debtor nations to reallocate educational spending toward primary and secondary schools. Meanwhile, authoritarian regimes suspected flagship universities of subversion and slashed their budgets. By the I99os, even the finest African universities were in crisis.
To compound these problems, the growth of secondary education drove a relentless demand for tertiary enrollments. Governments mandated their flagship universities to enroll far beyond their carrying capacities. New regional institutions were founded and tertiary technical colleges were granted university status. Nigeria, for example, had founded 86 federal and state universities by 20I5. Even with increases in funding, African higher education budgets lagged behind enrollment gains. Thousands of African academics left to find work elsewhere.

So what was to be done? In 200I, the World Bank reemphasized the universities' role in national development. After years of neglect, Western foreign aid programs retargeted higher education. Private funders returned; the "Partnership for Higher Education," for instance, which engaged eight American foundations with universities in nine African countries, invested $\$ 440$ million between 2000 and 20I0. African governments began to charter more private universities and technical schools. In Ghana, for example, there were just two private universities in I999, but now there are 28 .

\section{As Christian movements become strong national forces, their educational aims are broadening to engage larger social responsibilities.}

\section{The Expansion of Christian Universities}

Christian higher education has played a salient role in this rapid private growth. Nigeria has chartered 6I private institutions since I999. Of these, 3I are Christian. In Kenya, there are I7 chartered private universities and I3 more with interim authority. Of all these, I7 are Christian. This trend is quite dynamic across the continent. Indeed, sub-Saharan Africa is one of the "hot spots" in the growth of Christian higher education worldwide.

From a broad social and educational viewpoint, this Christian university movement seems driven by the massive demand for access to higher education and the liberalization of government chartering, both global trends. The religious scene in Africa, however, provides its own drivers of this movement. It is part of a larger effort to institutionalize, and thus conserve, the huge gains in Christian adherence. Christian groups in Africa often look first to the educational needs of their children, but they also move quickly to train clergy. In I950, there were only perhaps 70 or 80 pastoral education programs or theological schools across 
Africa, but a recent survey found I,468 of them.

As Christian movements become strong national forces, their educational aims are broadening to engage larger social responsibilities. Universities are a better fit than seminaries for these broader purposes, and more than a dozen of the new African universities have seminary or Bible college ancestry. Church people start these universities so their own youth can flourish, but the institutions also aim to build up the nation. Most are open to enrollees beyond their own young people.

\section{Challenging Mandates}

The Christian universities face some of the same challenges that confront other African universities. From the state's perspective, they exist to provide broader access, so their chartering often mandates steep enrollment increases and rapid development of new programs and campus facilities. Bowen University, a Baptist-founded institution in Southern Nigeria, opened with 500 students in 2002 and now enrolls 5,000. Covenant University, founded in 2002 by the Nigerian Pentecostal megachurch Winner's Chapel, now has I5,000 students. Uganda Christian University, an Anglican institution founded in 1997, now has more than Io,००० students. Officials cite rapid growth as both a blessing and a challenge; added tuitions help their budgets but strain their ability to recruit adequate instructors and add sufficient facilities.

Other challenges stem from Christian educational mandates. These institutions announce Christian purposes and perspectives for learning nonreligious subjects and they structure campus life to reflect Christian norms. Yet most of them welcome qualified students regardless of faith. Students might chafe at taking courses in religion and having religious orientations infused into what most of society sees as nonreligious subjects. Some are frustrated by chapel or behavior codes. Part-time professors, so common to African universities generally, do not see why their teaching might need to be different in a Christian context. State officials have decided to accommodate religious educational partners, but wonder why hiring criteria, curricular development, or student norms need to be different on Christian campuses.

These new Christian universities are very dynamic places, and their leaders express high hopes that they will help their nations flourish. But one of the main themes of higher education history has been secularization. Broad state purposes inevitably rub against religious particularity, even in highly religious Africa. Even so, Christian universities persist in the West and are rising up afresh in other realms. It is too soon to predict the trajectory of the African wing of the worldwide Christian university movement, but one cannot miss its growing presence and emerging challenges.

\section{Latin American Universities: Stuck in the Twentieth Century}

\section{Marcelo Knobel and Andrés Bernascon I}

Marcelo Knobel is professor at the Instituto de Física Gleb Wataghin (IFGW), University of Campinas (Unicamp), Campinas, SP, Brazil. Email: knobel@ifi.unicamp.br. Andrés Bernasconi is associate professor, Facultad de Educación, Pontificia Universidad Católica de Chile, Santiago de Chile, Chile.E-mail: abernasconi@uc.cl.

Tn 2018, Latin American universities will commemorate 1 the centennial of the Córdoba University Reform. This movement, and its aftermath, changed the idea of the university in Latin America, and ushered in an era of optimism about the social relevance of universities at the beginning of the twentieth century.

Universities have indeed played a role in the social, political, cultural, and economic development of Latin America, but have somehow fallen short (as has the region's development, generally). The twenty-first century finds higher education in a process of radical change, throughout North America, Europe, Asia, Oceania, and the Middle East, forging new "social contracts" with the communities that sustain them. Universities in Latin America, in contrast, seem firmly entrenched in a twentieth century mindset, discourse, and repertoire of functions.

Why is this so? Why are Latin American universities rarely places of radical innovation, stellar research performance, or forward-looking projects?

\section{Latin American Universities: Shaped by Accretion}

The first universities in the region were founded in the Spanish colonies during the sixteenth century. Their legacy of scholastic teaching and authoritarian governance persisted for the most part after independence and into the nineteenth century. After freedom from Spain and Portugal in the first decades of the eighteenth century, the universities embodied a model that awkwardly combined the Hispanic medieval tradition of Alcalá and Salamanca with the French Imperial University. 